Int. J. Electrochem. Sci., 14 (2019) $6406-6419$

International Journal of

ELECTROCHEMICAL

SCIENCE

WWW.electrochemsci.org

\title{
Evaluation of Leaf and Bark Extracts of Acacia tortilis as Corrosion Inhibitors for Mild Steel in Seawater: Experimental and Studies
}

\author{
Ismat H. Ali ${ }^{*}$, Abubakr M. Idris, Mohammed H. A. Suliman \\ Department of Chemistry, College of Science, King Khalid University, Abha, Saudi Arabia, P. O box \\ 9004 \\ *E-mail: ismathassanali@gmail.com
}

doi: $10.20964 / 2019.07 .10$

Received: 16 February 2019 / Accepted: 12 April 2019 / Published: 10 June 2019

Corrosion is a serious phenomenon affecting metals and alloys, which reduces the value and efficiency of metallic and alloyed products and shortens their lifetime. The aim of this study was to develop inexpensive and eco inhibitors extracted from abundant native plants in Asir region, Saudi Arabia. Phytochemical screening was carried out for the ethanolic extracts from leaves and barks. Polyphenols, phenolic compounds and flavonoids were found the major groups. Both potentiodynamic polarization curves and electrochemical impedance spectroscopy were used to investigate the efficiency of the inhibitors. The maximum achievable IE\% were $87.6 \%$ and $72.9 \%$ for ATL and ATB, respectively. The potentiodynamic polarization (PDP) tests revealed that both extracts act as mixed type inhibitors. The results obtained from electrochemical impedance spectroscopy (EIS) measurements indicate an increase in polarization resistance confirming the inhibitive capacity of tested inhibitors. The adsorption of the inhibitors on the steel surface follow Langmuir adsorption isotherm model and involves competitive physio-sorption and chemi-sorption mechanisms. EIS technique was utilized to investigate the effect of temperature on corrosion inhibition at $298 \mathrm{~K}-328 \mathrm{~K}$ temperature range. Results confirm that the inhibition efficiency (IE\%) of all inhibitors decrease slightly as temperature increases. The thermodynamic parameters for both inhibitors were calculated.

Keywords: Corrosion, Acacia tortilis, leaves, barks, steel, sea water

\section{$\underline{\text { FULL TEXT }}$}

(C) 2019 The Authors. Published by ESG (www.electrochemsci.org). This article is an open access article distributed under the terms and conditions of the Creative Commons Attribution license (http://creativecommons.org/licenses/by/4.0/). 